Article

\title{
Energy Efficiency of a Heat Pump System: Case Study in Two Pig Houses
}

\author{
Hannah Licharz ${ }^{1,2, *}$, Peter Rösmann ${ }^{3}$, Manuel S. Krommweh ${ }^{1}$, Ehab Mostafa ${ }^{4}$ and \\ Wolfgang Büscher ${ }^{1}$ (D) \\ 1 Institute of Agricultural Engineering, University of Bonn, Nußallee 5, 53115 Bonn, Germany; \\ krommweh@uni-bonn.de (M.S.K.); buescher@uni-bonn.de (W.B.) \\ 2 Institute of Animal Science, University of Bonn, Endenicher Allee 15, 53115 Bonn, Germany \\ 3 AGRAVIS Futtermittel GmbH (Animal Feeding Company), Industrieweg 110, 48115 Münster, Germany; \\ Peter.Roesmann@agravis.de \\ 4 Agricultural Engineering Department, Faculty of Agriculture, Cairo University, El-Gammaa Street, Giza \\ 12613, Egypt; ehababdelmoniem@hotmail.com \\ * Correspondence: hlicharz@uni-bonn.de; Tel.: +49-228-73-3081
}

Received: 19 December 2019; Accepted: 23 January 2020; Published: 4 February 2020

\begin{abstract}
This study describes a 70-day investigation of three identical groundwater heat pumps (GWHP) for heating two pig houses located on the same farm in West Germany. Two of the three GWHPs were installed in a piglet-rearing barn, the third in a farrowing barn. All three heat pumps were fed from the same extraction well. The aim of this study was firstly the empirical performance measurement of the GWHP systems and secondly the energetic evaluation of the systems on barn level by calculating the coefficient of performance (COP). Three different assessment limits were considered in order to better identify factors influencing the COP. In total, the heat pumps supplied thermal energy of $47,160 \mathrm{kWh}$ (piglet-rearing barn) and 36,500 kWh (farrowing barn). Depending on the assessment limit considered, the COP in piglet-rearing barn and farrowing barn ranged between 2.6-3.4 and 2.5-3.0, respectively. A significant factor influencing the COP is the amount of electrical current required to operate the groundwater feeding pump. The average groundwater flow rate was $168.4 \mathrm{~m}^{3} \mathrm{~d}^{-1}$ (piglet-rearing barn) and $99.1 \mathrm{~m}^{3} \mathrm{~d}^{-1}$ (farrowing barn). In conclusion, by using energy from groundwater, GWHPs have the potential to substitute fossil fuels, thus saving them and avoiding $\mathrm{CO}_{2}$ emissions.
\end{abstract}

Keywords: renewable energy; groundwater; livestock building; heating; coefficient of performance; climate change; resources; sustainability

\section{Introduction}

Against the background of limited fossil energy resources, the efficient use of energy and the sustainable use of energy resources play an important role worldwide. In addition, the reduction of greenhouse gas emissions is being sought in the context of climate change. In 2018, total greenhouse gas emissions in Germany amounted to 865.6 million tons of $\mathrm{CO}_{2}$ equivalents [1]. A total of 63.6 million tons of these emissions are attributable to agriculture [1]. This means that German agriculture was able to achieve a reduction of $4.1 \%$ compared with the previous year 2017 (66.3 million tons of $\mathrm{CO}_{2}$ equivalents from agriculture) [1]. However, there is still a need for action in agriculture and all other sectors in order to achieve national and international climate targets.

The demand for fossil fuels also plays a major role. The higher demand of the fast-growing economies of developing countries has led to high prices and decreasing fossil energy resource [2]. Consequently, the use of renewable energies, such as biogas, wind, and photovoltaic energy [2], and 
the use of geothermal energy is an important alternative to fossil fuels or energy from fossil fuels in general, but also in agriculture in particular (cf. [3]). This is an important reason for using heat pumps by substituting fossil fuels with other energy sources. Another reason is to become more independent of the energy price.

In pig housing, a good indoor climate must be available to the animals to satisfy the legislation regarding animal welfare demands and the thermal and physical requirements to ensure building protection. Due to the high temperature demand of piglets, the energy consumption during the rearing phase is relatively high. Thus, the average yearly energy consumption under German conditions is approximately $300 \mathrm{kWh}$ per sow, including piglet rearing [4]. In Germany, pigs are typically housed in insulated buildings with forced ventilation. To maintain thermal welfare, just-born piglets require $35-37{ }^{\circ} \mathrm{C}, 28-32{ }^{\circ} \mathrm{C}$ in the first week postpartum (pp) and $25-27^{\circ} \mathrm{C}$ in the later rearing phase $[5,6]$. The optimal surface temperature in the lying area should be $38-39{ }^{\circ} \mathrm{C}$ in the first week pp; for older piglets, the floor temperature in the lying area should be kept at $33-36{ }^{\circ} \mathrm{C}$ [7]. When planning a pig house in Germany, regulation DIN 18910 [8] must be considered; this regulation describes the calculation methods used to estimate the heat demand at the house level considering the air volume flow under summer and winter conditions. An example calculation is described by Büscher et al. [9]. In livestock buildings, the energy losses by ventilation are relatively high, making up 70 to $90 \%$ of the building's total heat losses [10-12]. Heat recovery systems are used to reduce these energy losses through ventilation of mechanically ventilated livestock buildings to transfer heat of the exhaust air to the incoming fresh air [13] (cf. $[10,14,15])$. In addition, systems using renewable energy for heating are and have been investigated and evaluated under practical conditions. Different technologies for heating pig housings using renewable energy are available, for example, a modular housing system with an integrated geothermal heat exchanger [3] or heat pump.

Basically, heat pumps extract heat from an energy source, which can be air, groundwater, or soil [16] (cf. Figure 1) by evaporating a refrigerant. With this system, the refrigerant is contained in a closed circuit and is guided to a compressor. Due to the compressing process, the gas changes to the liquid phase, and the energy can be transferred to another medium (e.g., to water circulating in a floor-heating system). The working medium is refrigerant that evaporates at a relatively low temperature. It recirculates between the energy source and the heat pump, changing its aggregation condition by the processes of evaporating, compressing, liquefying, and expanding, as shown in Figure 1. This heat transfer from "cold" to "hot" does not run automatically. The system consumes electricity for circulation pumps and compressors [17,18].

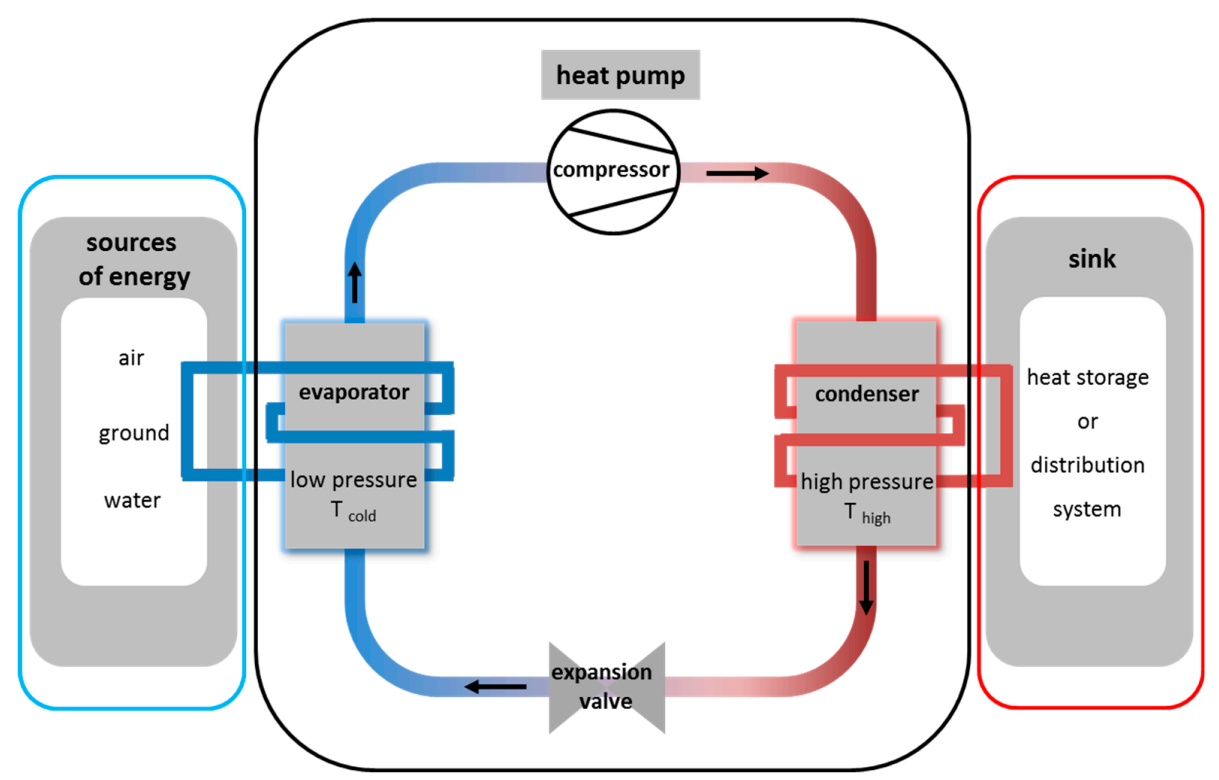

Figure 1. Principle and functional elements of a heat pump. 
The temperature level of the heating system should be as low as possible (e.g., $35^{\circ} \mathrm{C}$ ) because of the decreasing efficiency of heat pumps for higher outgoing temperatures [18] (cf. [19]). Heat pumps can also be used to produce higher water temperatures in the heating systems (e.g., $55-65^{\circ} \mathrm{C}$ ) but only with low efficiency [18]. To make a comparison of different heat pumps regarding the COP (coefficient of performance) (see Equation (1)) on a test bench, the temperatures of the source and the sink medium have to be examined under defined conditions [20]. To determine the COP of heat pumps for planning aspects, the specific practical conditions of the installation must be regarded, considering other electricity consumers, such as the pumps for the circulation of hot water to distribute the heat energy inside the barn.

$$
C O P_{H P}=\frac{\dot{Q}_{H P}}{P_{H P}}
$$

with $\mathrm{COP}_{\mathrm{HP}}$ : coefficient of performance of heat pump; $\dot{\mathrm{Q}}_{\mathrm{HP}}$ : heating performance of heat pump in $\mathrm{kW} ; \mathrm{P}_{\mathrm{HP}}$ : electrical power consumption of heat pump in $\mathrm{kW}$.

In heat pump systems, a distinction is made between open and closed systems. Open systems use groundwater or water from surface waters (pond, lake, or similar) as heat transfer medium, whereby the water is transported directly to the heat pump. After passing through the heat pump, the water is pumped into a rejection well or back into the surface waters. Closed systems are systems with a closed pipe system containing a heat transfer medium. The heat transfer medium circulates continuously through the pipe system and thus transports heat energy from the ground to the heat pump. Furthermore, heat pump systems differ in the design of the pipes, which can be arranged horizontally (laid close to the surface in the ground, 1-2 m deep) or vertically (reaching deep into the ground, up to $450 \mathrm{~m}$ deep $[19,21])$. In any case, a number of factors should be considered during the planning phase, which Omer summarizes well as follows: "geology and hydrogeology of the underground (sufficient permeability is a must for open systems), area and utilisation on the surface (horizontal closed systems require a certain area), existence of potential heat sources like mines, and the heating and cooling characteristics of the building(s)." [21] (p. 356). A detailed description of the various heat pump systems with their advantages and disadvantages is given in particular by Omar [21] and Ahmadi et al. [22].

When planning the use of a groundwater heat pump in Germany, it must be remembered that the use of groundwater is regulated by various laws. One important law is the Water Resources Act. Depending on the site, the Federal Mining Act may also apply. Every deep drilling requires the water law approval of the local district office (especially the water authority). It is checked whether the planned drilling site is located in a protected area (nature reserve, water protection area, or similar), as drilling is usually prohibited there. Other aspects that are normally checked are the quantity of groundwater available at the site as well as quality and flow velocity of the groundwater (cf. [17]). It may also be necessary to prepare a geological survey to clarify the soil conditions in deeper layers.

In Germany, but also in other European countries and worldwide, heat pumps of various designs are frequently used in residential buildings, office buildings, and in industry [22-25]. In agriculture, heat pumps are used, for example, to dry medicinal plants [26] or to heat greenhouses $[27,28]$. Not too many publications deal with the use of heat pumps for heating animal stables [17,29-36]. While Manolakos et al. [32] developed a model for a system, which uses heat pumps in a HVAC (heating, ventilation, and air conditioning) system for precise environment control in broiler houses (cf. [37]), only five of these publications $[29,31,33,34,36]$ report on practical experiments with heat pump systems. The present study should help to close this gap.

Cremer [29] examined a farrowing barn with 40 animal places, in which a brine heat pump (15 kW nominal heating capacity; area collector) was used to heat the piglet nests. The heat pump produced $32,000 \mathrm{kWh}$ thermal energy and had a COP of 4.0 in the one-year period of the study. The author states that the use of the heat pump saved $52 \%$ of energy costs compared to the use of an oil heating system. However, in calculating the COP, the author only considered the electricity consumption of the heat pump itself, but not that of the brine pump and the circulation pumps of the distribution system in the 
house. Furthermore, Cremer investigated an outdoor climate piglet-rearing house (1100 animal places) with a brine heat pump (16 kW nominal heating capacity; area collector) connected to a floor heating system in the cubicles [29]. During the 21-week study period, a total of 25,467 kWh of thermal energy was provided. Taking into account all relevant electricity consumers, $9961 \mathrm{kWh}$ of electric power was required, resulting in a COP of 2.6 [29]. The potential of heat pump technologies in animal houses is anticipated to be high because temperature of the buffer reservoir of the floor-heating systems are relatively low $\left(45^{\circ} \mathrm{C}\right)$, and water-distribution systems are established in most cases [29]. Nevertheless, the requirements for a heat pump system in an animal house are different from those for residential or office buildings. In a pigsty, significantly higher temperatures in the animal area are to be achieved; for piglets between $25^{\circ} \mathrm{C}$ and $37^{\circ} \mathrm{C}$ (see paragraph above). Furthermore, mechanically ventilated livestock buildings are ventilated much more intensively than residential or office buildings, which is associated with higher heat losses via the heated exhaust air. Since a heat pump, depending on its dimensions, is not always able to cover a high heat requirement in the barn with cold outside air temperatures at the same time, it is not unusual that in practice another heating technology (hot air blower) is also used in order to still be able to guarantee the required barn interior temperature at these times.

The aim of this study was (1) the 70-day study of a farrowing barn and a piglet-rearing barn with identical heat pump types at the same location and (2) the energetic evaluation of the systems at barn level by calculating the coefficient of performance (COP). Three different assessment limits were considered in order to better identify factors influencing the performance. These are

1. $\mathrm{COP}_{\mathrm{T}}$ : the thermal output was set in relation to the total amount of electricity used for pumping medium (ground water pump), heat pump itself (compressors), circulation pumps of the heat pump, and distribution system (circulation pumps for hot water distribution in the house).

2. $\mathrm{COP}_{\mathrm{P}}$ : the thermal output was set in relation to the amount of electricity used for pumping medium (groundwater pump) and the heat pump itself (compressors).

3. $\mathrm{COP}_{\mathrm{Z}}$ : the thermal output was set in relation to the amount of electricity used for the heat pump itself (compressors), circulation pumps of heat pump, and distribution system (circulation pumps for hot water distribution in the barn).

\section{Materials and Methods}

A case study from 8 December 2011 to 15 February 2012 was conducted to examine the studied heat pumps. The field experiments were performed in two forced-ventilated pig buildings (Figure 2) located in a district of Recklinghausen, West Germany. The district of Recklinghausen is located $440 \mathrm{~km}$ southwest of Berlin, $520 \mathrm{~km}$ northwest of Munich, $90 \mathrm{~km}$ north of Cologne, and $80 \mathrm{~km}$ east of Nijmegen (The Netherlands). These buildings were thermally insulated; the transition transfer coefficient of the entire building was $0.3 \mathrm{~W} \mathrm{~m}^{-2} \mathrm{~K}^{-1}$ (U-value) on average. According to the seasonal effects, three identical groundwater heat pumps (GWHPs) (Fighter 1330, NIBE Systemtechnik GmbH, Celle, Germany) were investigated. The first heat pump was installed in a farrowing barn with a total floor area of $3256 \mathrm{~m}^{2}$ (88 $\mathrm{m}$ length $\times 37 \mathrm{~m}$ width), whereas the other two pumps were installed in the piglet-rearing barn with a total floor area of $2135 \mathrm{~m}^{2}(61 \mathrm{~m}$ length $\times 35 \mathrm{~m}$ width). Each heat pump consisted of two modules (A and B). Both barns are a part of a farm with 740 sows, which are used for gilt reproduction. The farrowing and piglet-rearing barns were rebuilt away from the urbanized area in 2009. 

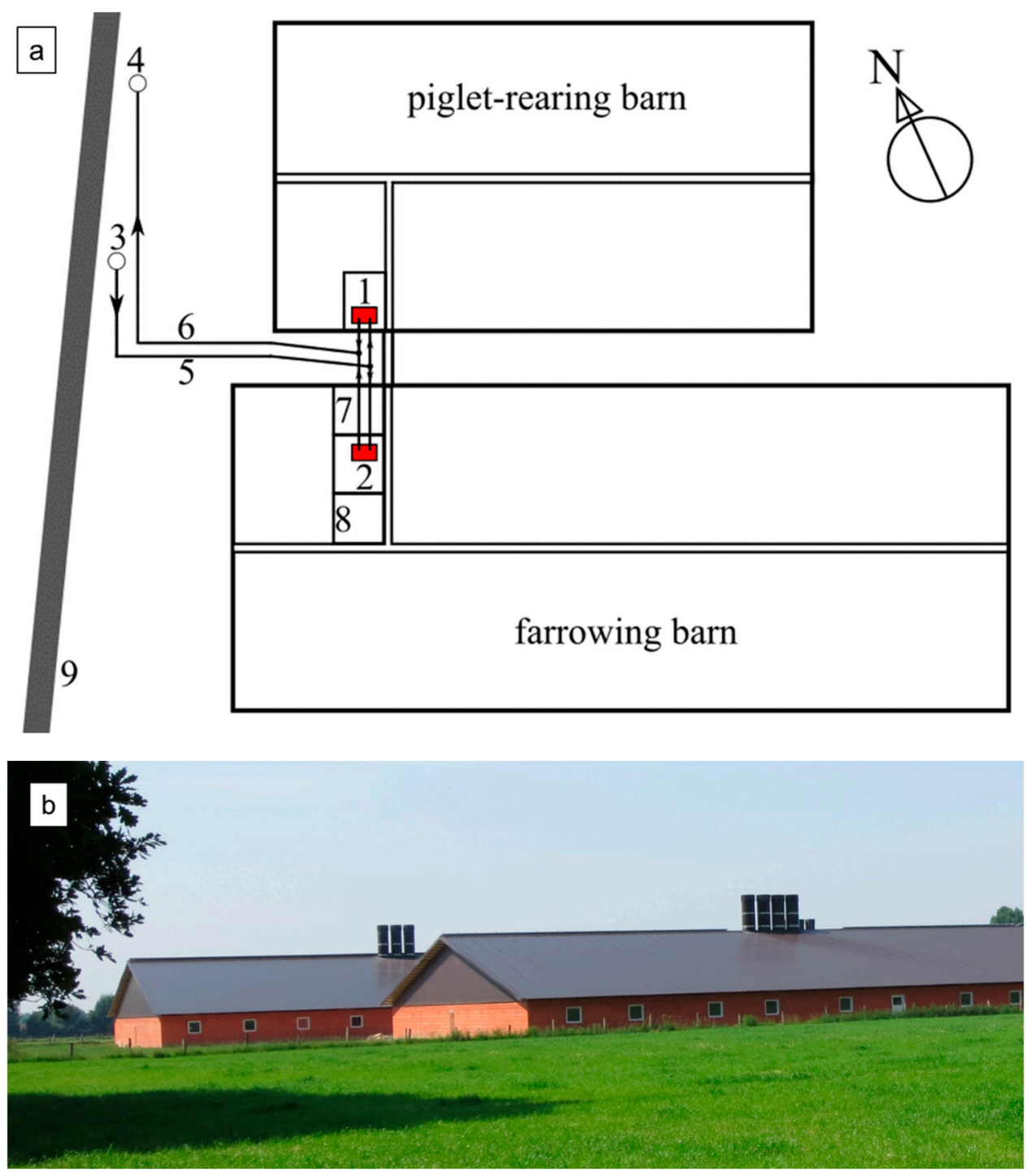

Figure 2. (a) Sketch of the floor plan of the barn and (b) exterior view of the barn from the north-west side. 1: heat pumps piglet-rearing barn; 2 : heat pump farrowing barn; 3: extraction well with groundwater feeding pump; 4: rejection well; 5: groundwater inlet pipe; 6: groundwater outlet pipe; 7 : entrance and hygiene lock; 8: barn office; 9: road.

\subsection{Description of the Experimental Setup}

The farrowing barn consisted of 172 places divided into four compartments. Each compartment had 38 farrowing pens in addition to an extra compartment with 20 farrowing pens. Each pen was equipped with a $0.65 \mathrm{~m}^{2}$ warm-water piglet heater supplied by the heat pump. For better animal control, no additional thermal insulation covers for the piglet nests were installed. However, additional 100-W infrared heat lamps were used during the new-born piglets' first days. Together, the two modules of the heat pump had a nominal heating capacity of $40 \mathrm{~kW}$. In this barn, modules A and B fed different reservoirs, and module A was responsible for controlling the temperature of the buffer reservoir (500 L) at approximately $45^{\circ} \mathrm{C}$. This serves as a heat source for the warm-water piglet heater. The heat pump of module B was a heat source for the water reservoir ( $300 \mathrm{~L}$; domestic/service water) and ensured that the water temperature in the reservoir was maintained at approximately $50{ }^{\circ} \mathrm{C}$ (Figure 3a). 

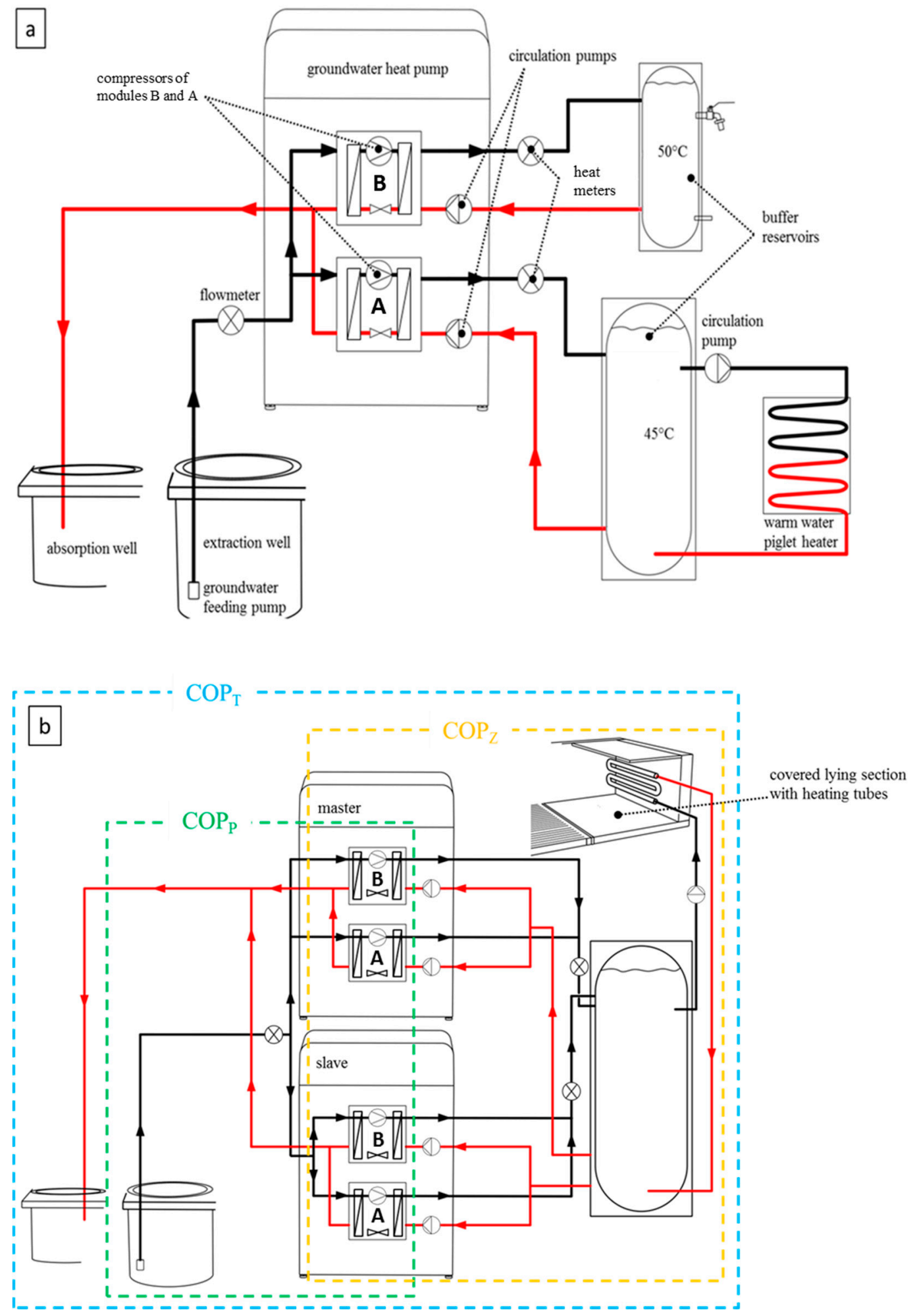

Figure 3. Installation diagram of (a) the heat pumps in the farrowing barn with experiment instrumentations and (b) piglet-rearing barns with the assessment limits for the determination of the coefficient of performance (COP).

The piglet-rearing barn was divided into eight equal compartments, each with 500 finishing pig places. The compartments were heated by four parallel steel tubes with a diameter of $63 \mathrm{~mm}$. These tubes were mounted on the wall one above the other and the warm water from the heat pump 
flowed through them. The lying areas of the compartments were provided with heat-protection covers. The compartment temperature depended on the animals' ages and ranged between $32{ }^{\circ} \mathrm{C}$ and $24{ }^{\circ} \mathrm{C}$. When the temperature of the compartment decreased by more than $2{ }^{\circ} \mathrm{C}$ below the setpoint temperature, an additional 10-kW liquid petroleum gas (LPG) hot air blower turned on automatically. Before restocking the compartments with new animals or to dry the compartments after a cleaning process, 30-kW hot air blowers heated the compartments. Two GWHPs were regularly used to heat the compartments. These pumps were installed in master-slave combination modules; accordingly, the master heat pump operates separately with low heating capacity requirements. The slave heat pump was controlled by the master heat pump and operated only in conditions requiring high heating. All four modules of the two heat pumps were used to supply a 1500-L buffer reservoir with a target temperature of $50^{\circ} \mathrm{C}$ (Figure 3b).

A groundwater temperature of approximately $10{ }^{\circ} \mathrm{C}$ served as a heat source for both heating circuits of the farrowing and piglet-rearing barns. A frequency-controlled groundwater pump (7.5 $\mathrm{kW} \max 40 \mathrm{~m}^{3} \mathrm{~h}^{-1}$ ) extracted the groundwater from common extraction well with a depth of 110 $\mathrm{m}$. The groundwater circulated with an operating pressure of 1.3 bar through the heat pump and transferred its heat energy to the working equipment. Once the water passed through the heat pump, it was pumped again into the rejection well, which was $70 \mathrm{~m}$ deep and located $20 \mathrm{~m}$ away from the extraction well (Figures 2a and 3). The GWHPs of the farrowing and piglet-weaning barn operated independently. Consequently, these two systems can be directly compared.

\subsection{Experiment Instrumentations}

Four calibrated ALLMESS ultrasonic heat meters (CF Echo II, ALLMESS GmbH, Oldenburg, Germany) were used to measure the heat generated from the groundwater in kilowatt hours $(\mathrm{kWh})$. These sensors had a measuring range for water from 0 to $180{ }^{\circ} \mathrm{C}$ with an accuracy of $\pm 5 \%$. To estimate the total amount of water passed through the system, three calibrated flowmeters were used to observe both the groundwater flow for the heat pump systems and the drinking water supply network. Recording both the total amount of water and the water supply of the investigated stables was necessary because both were driven to the same groundwater-feeding pump. In parallel, the energy requirements of the groundwater-feeding pump were recorded using a three-phase meter, to which each groundwater consumer (farrowing or piglet-weaning barn) could be subsequently quantitatively assigned. To achieve energetic comparability of the heat pump systems, an additional electric energy requirement for both pumps was separately detected using three-phase meters. The LPG consumption of the piglet-rearing barn (in $\mathrm{m}^{3}$ ) was determined using a calibrated liquid counter (RS/2001AL, Samgas, Vernate Milano, Italy). The outside and inside temperatures of both stables were recorded using temperature data loggers (Testo T175 T1 AG, Lenzkirchen, Germany) with integrated negative temperature coefficient thermistors as sensors. The range of measurement of the sensors was from -35 to $+70{ }^{\circ} \mathrm{C}$ within $\pm 0.5^{\circ} \mathrm{C}$ accuracy.

A special heat pump software program (NIBE, Systemtechnik) was used to record several operating parameters continuously, including the working hours for each heat pump and the input and output groundwater temperatures of the heat pump in degrees Celsius.

\subsection{Assessment Limits and COP Calculation}

In practice, the efficiency of the heat pump is expressed by the COP (see Equation (1)). Therefore, various possible assessment limits at barn level were used to consider the number of used electrical loads in the system to determine the different efficiency levels of a heating circuit and to carry out weak point analysis of the whole heating circuit. Accordingly, three assessment limits are defined and represented in Figure 3b. 
The assessment limits vary depending on the considered number of electrical consumers (Figure $3 b$ ). The three assessment limits $\mathrm{COP}_{\mathrm{T}}$ (Equation (2)), $\mathrm{COP}_{\mathrm{P}}$ (Equation (3)), and $\mathrm{COP}_{\mathrm{Z}}$ (Equation (4)) were calculated. They are explained in detail as follows:

$$
C O P_{T}=\frac{\mathrm{Q}_{\mathrm{HP}}}{\mathrm{P}_{\mathrm{GFP}}+\mathrm{P}_{\mathrm{CO}, A+B}+\mathrm{P}_{\mathrm{CI}, A+B}+\mathrm{P}_{\mathrm{CI}, \mathrm{FB} \text { or } \mathrm{CI}, \mathrm{RB}}}
$$

with

- $\mathrm{COP}_{\mathrm{T}}$ : coefficient of performance of the total heating circuit;

- $\mathrm{Q}_{\mathrm{HP}}$ : thermal heating energy in $\mathrm{kWh}$;

- $P_{\text {GFP: }}$ electrical expenditure of the groundwater feeding pump in $\mathrm{kWh}$;

- $\quad \mathrm{P}_{\mathrm{CO}, \mathrm{A}+\mathrm{B}}$ : electrical expenditure of compressors $\mathrm{A}+\mathrm{B}$ (in piglet rearing for both heat pumps) in $\mathrm{kWh}$;

- $\mathrm{P}_{\mathrm{CI}, \mathrm{A}+\mathrm{B}}$ : electrical expenditure of circulation pumps $\mathrm{A}+\mathrm{B}$ of the heat pump in $\mathrm{kWh}$;

- $\mathrm{P}_{\mathrm{CI}, \mathrm{FB} \text { or } \mathrm{CI}, \mathrm{RB}}$ : electrical expenditure of the circulation pump for the farrowing or piglet-rearing barns in $\mathrm{kWh}$.

$$
C O P_{P}=\frac{\mathrm{Q}_{\mathrm{HP}}}{\mathrm{P}_{G F P}+\mathrm{P}_{\mathrm{CO}, A+B}}
$$

with

- $\mathrm{COP}_{\mathrm{P}}$ : coefficient of performance of the groundwater feeding pump and the electrical expenditure of compressors $\mathrm{A}+\mathrm{B}$ (in piglet rearing for both heat pumps);

- $\mathrm{Q}_{\mathrm{HP}}$ : thermal heating energy in kWh;

- $P_{\mathrm{GFP}}$ : electrical expenditure of the groundwater feeding pump in $\mathrm{kWh}$;

- $\quad \mathrm{P}_{\mathrm{CO}, \mathrm{A}+\mathrm{B}}$ : electrical expenditure of compressors $\mathrm{A}+\mathrm{B}$ (in piglet rearing for both heat pumps) in $\mathrm{kWh}$;

$$
C O P_{Z}=\frac{\mathrm{Q}_{\mathrm{HP}}}{\mathrm{P}_{\mathrm{CO}, A+B}+\mathrm{P}_{C I, A+B}+\mathrm{P}_{\mathrm{CI}, \mathrm{FB} \text { or } \mathrm{Cl}, \mathrm{RB}}}
$$

with

- $\mathrm{COP}_{\mathrm{Z}}$ : coefficient of performance of the total heating circuit without the electrical expenditure of groundwater feeding pump;

- $\mathrm{Q}_{\mathrm{HP}}$ : thermal heating energy in $\mathrm{kWh}$;

- $\mathrm{P}_{\mathrm{CO}, \mathrm{A}+\mathrm{B}}$ : electrical expenditure of compressors $\mathrm{A}+\mathrm{B}$ (in piglet rearing for both heat pumps) in $\mathrm{kWh}$;

- $\quad \mathrm{P}_{\mathrm{CI}, \mathrm{A}+\mathrm{B}}$ : electrical expenditure of circulation pumps $\mathrm{A}+\mathrm{B}$ of the heat pump in $\mathrm{kWh}$;

- $\quad \mathrm{P}_{\mathrm{CI}, \mathrm{FB}}$ or $\mathrm{CI}, \mathrm{RB}$ : electrical expenditure of the circulation pump for the farrowing or piglet-rearing barns in $\mathrm{kWh}$.

\subsection{Data Analysis}

The data collected during the entire investigation period were analyzed using Microsoft Excel 2010. In this descriptive representation the study focused arithmetic mean $\bar{x}$, median $\widetilde{x}$, and the maximum performance potential of the heat pumps under winter conditions.

\section{Results}

\subsection{Climatic Conditions during the Experimental Periods}

The average outside air temperature at the experimental period was $2.0^{\circ} \mathrm{C}\left(\widetilde{\mathrm{x}}=3.5^{\circ} \mathrm{C}\right.$ ) (Figure 4 ). The maximum measured value was $12.8^{\circ} \mathrm{C}$, and the minimum was $-15.2{ }^{\circ} \mathrm{C}$. The air temperature in 
the farrowing barn was nearly constant and averaged $23.0^{\circ} \mathrm{C}\left(\widetilde{\mathrm{x}}=23.1^{\circ} \mathrm{C}\right.$ ) (Figure 4a). Whereas the maximum air temperature in the piglet-rearing barn was $34.0^{\circ} \mathrm{C}$ and at the end of the rearing period, the compartment air temperature was continuously decreased to $25.0^{\circ} \mathrm{C}$ (Figure $4 \mathrm{~b}$ ). The averaged air temperature was $28.4^{\circ} \mathrm{C}\left(\widetilde{\mathrm{x}}=28.1^{\circ} \mathrm{C}\right)$. The temperature drops in Figure 4 each indicate that the barn is empty.
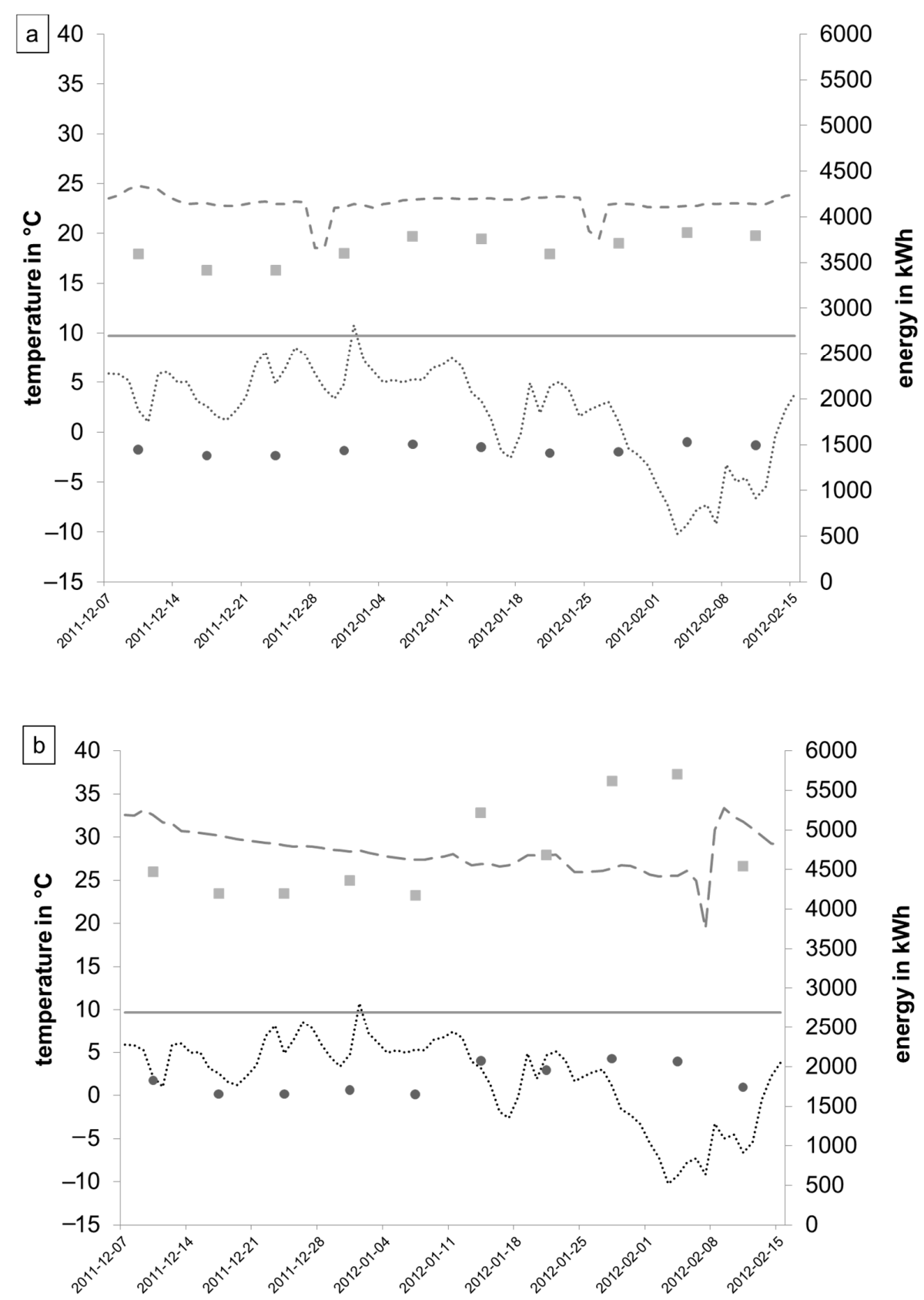

Figure 4. Temperature profiles (hourly mean values) as well as performance of the heat pump(s) (weekly mean values) in (a) the farrowing bran and (b) the piglet-rearing barn during the trial period. Dotted black line: outside air temperature; dashed grey line: barn inside air temperature; continuous grey line: groundwater temperature; black spots: electrical power consumption of heat pump(s); grey rectangles: heat supplied by the heat pump(s). 


\subsection{Utilization of Groundwater Heat Pumps}

The software of the GWHP read the operating hours of compressors A and B and stored them in the internal data memory. The cumulative data are presented in Figure 5.

a
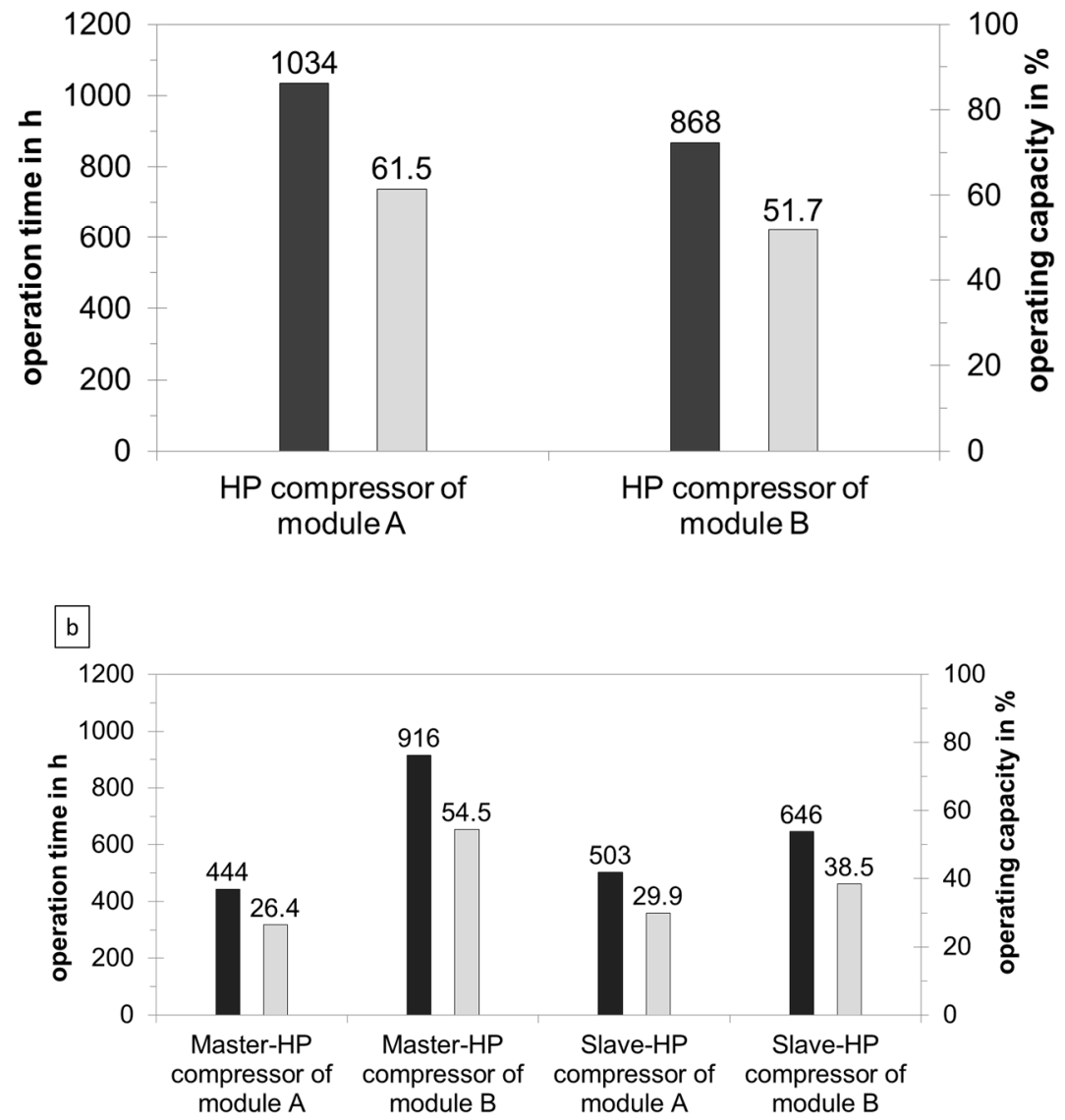

Figure 5. Operating hours (black column) and operating capacity (grey column) of (a) heat pump compressors in the farrowing barn and (b) piglet-rearing barn during the 70-day trial period, which correspond $1680 \mathrm{~h}$.

In addition to the absolute operating hours of the compressors, the relative operating capacities of the compressors were also specified. During the experimental period of 70 days (cf. Section 2), the operating hours of compressor A in the farrowing barn totaled $1034 \mathrm{~h}$ of the 1680 possible hours, which corresponds to an operating capacity of $61.5 \%$. Compressor B reached 868 operating hours with an operating capacity of $51.7 \%$ (cf. Figure $5 a$ ).

The four heat pump compressors were operated for a total of $2509 \mathrm{~h}$ in the piglet-rearing barn during the investigation period, which corresponds to an average operating capacity of $37.3 \%$ for the whole system. The compressors of the master heat pump were operated $211 \mathrm{~h}$ longer than the cumulative operating times of the two modules (compressors) of the slave heat pump. The highest operating capacity $(54.5 \%)$ was observed at compressor B of the master module with 916 operating hours (Figure 5b).

\subsection{Coefficient of Performance (COP) of the Groundwater Heating Pumps}

Figure 4 shows the temperature profiles of groundwater, outside air and inside air as well as the consumption of electric power (input) and the thermal power generated by the heat pumps (output) 
during the trial period for the farrowing barn (Figure 4a) and the piglet-rearing barn (Figure $4 \mathrm{~b}$ ). Both figures show in different ways that when outside air temperatures decrease, the power consumption of the heat pumps increases as well as the thermal output of the heat pumps, and vice versa.

Figure 6 shows the electric energy consumption considering the three assessment limits (see Equations (2)-(4) and Figure 3b) and the generated usable heat energy for both the farrowing barn (Figure 6a) and the piglet-rearing barn (Figure 6b).

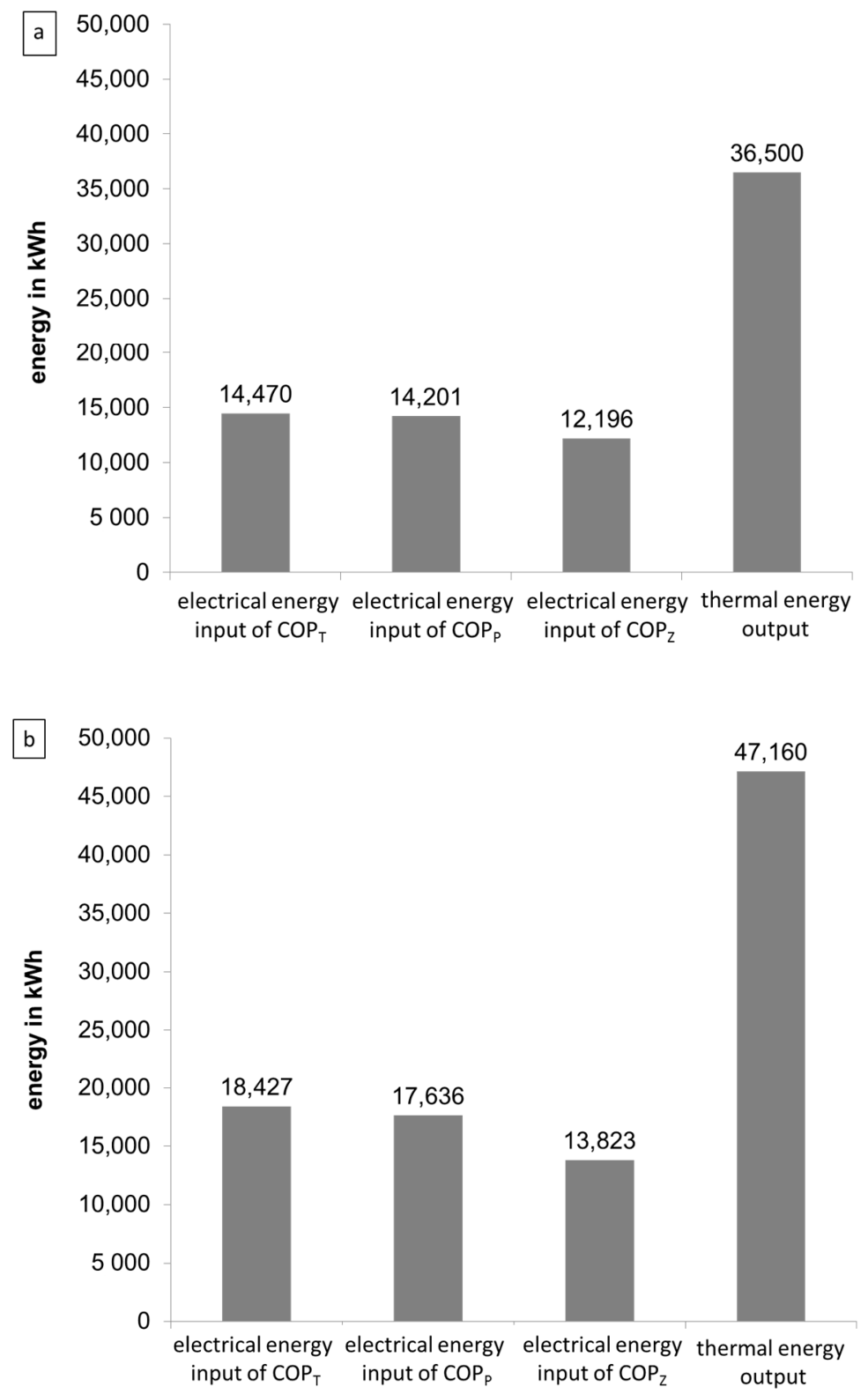

Figure 6. Electrical energy input depended on the different assessment limits (see Section 2.3) and thermal energy output during the experimental period in (a) the farrowing barn and in (b) the piglet-rearing barn.

The total consumed energy during the whole measuring period of the heat pump and the groundwater feeding pump (GFP) in the farrowing barn was 14,201 kWh (Figure 6a). During the same period, the heat pump provided $36,500 \mathrm{kWh}$ of total utilized thermal energy. Accordingly, the $\mathrm{COP}_{\mathrm{P}}$ value reached 2.6. After adding the electricity consumption of $269 \mathrm{kWh}_{\mathrm{el}}$ by the three circulation 
pumps for the heating circuits the $\mathrm{COP}_{\mathrm{T}}$ decreased to 2.5. Considering the overall system without the electricity consumption of the GFP resulted in a $\mathrm{COP}_{\mathrm{Z}}$ of 3.0 (cf. Figure 6a and Table 1).

Table 1. Comparison of two heat pump systems of two studies.

\begin{tabular}{|c|c|c|c|c|}
\hline $\begin{array}{l}\text { Heat Pump } \\
\text { System }\end{array}$ & $\begin{array}{l}\text { GWHP } \\
\text { [cf. 36] }\end{array}$ & $\begin{array}{l}\text { GWHP } \\
\text { [cf. 36] }\end{array}$ & $\begin{array}{c}\text { Brine heat Pump } \\
\text { with Area } \\
\text { Collectors [29] }\end{array}$ & $\begin{array}{c}\text { Brine Heat Pump } \\
\text { with Area } \\
\text { Collectors [29] }\end{array}$ \\
\hline Source & Groundwater & Groundwater & Ground & Ground \\
\hline $\begin{array}{c}\text { Types of livestock } \\
\text { housing }\end{array}$ & Piglet-rearing barn & Farrowing barn & Piglet-rearing barn & Farrowing barn \\
\hline $\begin{array}{l}\text { Experimental } \\
\text { period in } d\end{array}$ & 70 & 70 & 146 & 364 \\
\hline $\begin{array}{c}\text { Electricity } \\
\text { consumption } \\
\text { in } \mathrm{kWh}_{\mathrm{el}} \\
\text { - HP with } \\
\text { circulation pumps }\end{array}$ & 13,823 & 12,196 & 6725 & 8000 \\
\hline $\begin{array}{l}\text { - HP with GFP or } \\
\text { brine pump } \\
\text { - HP with }\end{array}$ & 17,636 & 14,201 & 8732 & - \\
\hline $\begin{array}{c}\text { circulation pumps } \\
\text { and GFP or brine } \\
\text { pump }\end{array}$ & 18,427 & 14,470 & 9961 & - \\
\hline $\begin{array}{c}\Sigma \text { Heat output } \\
\text { in } \mathrm{kWh}_{\mathrm{th}}\end{array}$ & 47,160 & 36,500 & 25,467 & 32,000 \\
\hline $\mathrm{COP}_{\mathrm{Z}}$ & 3.4 & 3 & 3.8 & 4 \\
\hline $\mathrm{COP}_{\mathrm{P}}$ & 2.7 & 2.6 & 2.6 & - \\
\hline $\mathrm{COP}_{\mathrm{T}}$ & 2.6 & 2.5 & 2.6 & - \\
\hline
\end{tabular}

For the master-slave heat pump in the piglet-rearing barn, $17,636 \mathrm{kWh}_{\mathrm{el}}$ was consumed by the heat pump and the GFP (Figure $6 \mathrm{~b}$ ). For heating over the same period, the heat pump provided $47,160 \mathrm{kWh}_{\text {th }}$ of utilizable heat. The COP of the heat pump was calculated similarly to the COP of the heat pump in the farrowing barn using Equations (2)-(4). The calculated values for $\mathrm{COP}_{\mathrm{P}}$ and $\mathrm{COP}_{\mathrm{T}}$ were 2.7 and 2.6, respectively. However, the $\mathrm{COP}_{Z}$ value was 3.4 for the heat pump system without considering the GFP (cf. Figure $6 \mathrm{~b}$ and Table 1 ).

\subsection{Heat Quantity and Produced Heating Capacity}

A complement of the required heating capacity of the heat pump was represented to provide the necessary heat quantity. A total of 36,160 kWh of thermal energy provided by the heat pump was used to heat the warm water flowing through the piglet nests (farrowing barn). Therefore, each piglet nest used $3.0 \mathrm{kWh}$ daily in winter. During the experimental period, an average of $23 \mathrm{~kW}$ of power was retrieved, representing approximately $57.5 \%$ of the maximum heat pump manufacturer's specifications.

The piglet-rearing barn was supplied with a total of $55,216 \mathrm{kWh}_{\text {th }}$ using a hot air blower and GWHP with a share of $47,160 \mathrm{kWh}_{\text {th }}$ during the experimental period. The heat pump provided $85.4 \%$ of thermal energy, whereas the hot air blower produced $14.6 \%$. The average equivalent value was approximately $790 \mathrm{kWh}$ per day or $0.2 \mathrm{kWh}$ per fattening place and day. The required heating capacity for the piglet-rearing barn was calculated by considering the heat pump and hot air blower as an average of $37 \mathrm{~kW}(\sigma=7.9 \mathrm{~kW} ; \widetilde{\mathrm{x}}=36.1 \mathrm{~kW})$. This value corresponds to an average of $46.3 \%$ of the maximum system performance for the master-slave configuration. 


\subsection{Groundwater Flow Rates}

For the heat pump applications in the farrowing and piglet-rearing barns, approximately $18,049 \mathrm{~m}^{3}$ of groundwater was obtained from the extraction well during the experimental period. This groundwater passed through the heat pump and then fed into the rejection well. This equivalent daily groundwater requirement is specified under the combined operating loads in Figure $5 \mathrm{a}, \mathrm{b}$ as $258 \mathrm{~m}^{3}$. The groundwater enters at a constant supply temperature of $\bar{x}=9.7^{\circ} \mathrm{C}\left(\sigma=0.1{ }^{\circ} \mathrm{C} ; \widetilde{\mathrm{x}}=\right.$ $\left.9.7^{\circ} \mathrm{C}\right)$ in the heat pump (Figure 4$)$ and leaves it with an average temperature of $6.7^{\circ} \mathrm{C}\left(\sigma=1.4^{\circ} \mathrm{C}\right.$; $\widetilde{\mathrm{x}}=6.7^{\circ} \mathrm{C}$ ). The groundwater was consequently cooled in the heat pump by an average of $3.0^{\circ} \mathrm{C}$. Approximately $3.5 \mathrm{kWh}_{\mathrm{th}} \mathrm{m}^{-3}$ of thermal energy is used to process the groundwater through the heat pump on average.

The water quantity is specified as shown in Figure 7 and was promoted daily by the heat pumps and the ratio between the daily amount of produced heat and the daily groundwater flow through the systems.

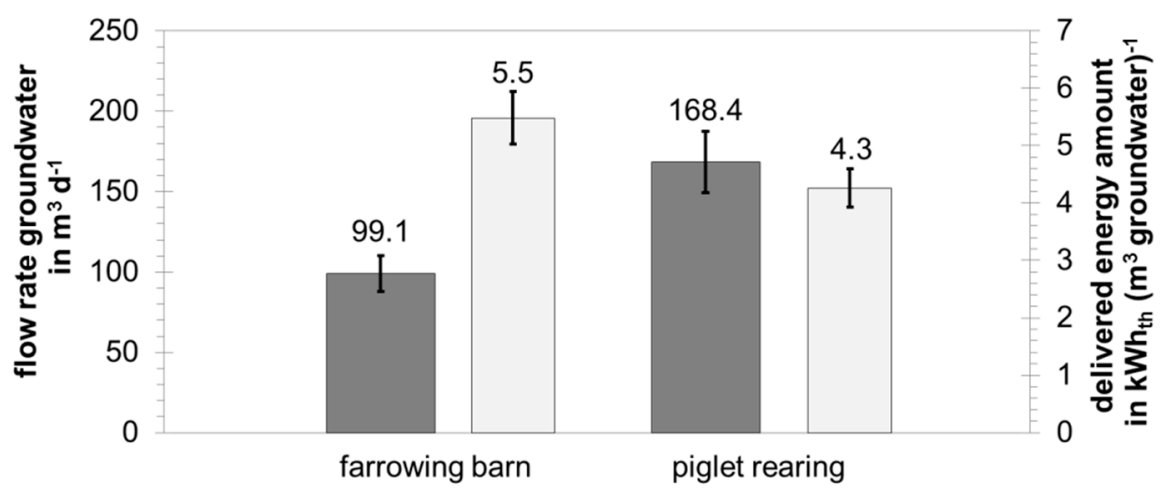

Figure 7. Daily groundwater flow rate (dark column) through the heat pumps and the achieved thermal energy per $\mathrm{m}^{3}$ groundwater (light column). The equivalent standard deviations are also presented.

The farrowing barn was provided with purposed heat using the heat pump with an average of $5.5 \mathrm{kWh}_{\text {th }}$ for each cubic meter of groundwater $\left(\sigma=0.5 \mathrm{kWh}_{\mathrm{th}} \mathrm{m}^{-3} ; \widetilde{\mathrm{x}}=5.5 \mathrm{kWh}_{\mathrm{th}} \mathrm{m}^{-3}\right)$. The piglet-rearing barn was provided with average purposed heat of $4.3 \mathrm{kWh}_{\mathrm{th}} \mathrm{m}^{-3}\left(\sigma=0.3 \mathrm{kWh}_{\mathrm{th}}\right.$ $\mathrm{m}^{-3} ; \widetilde{\mathrm{x}}=4.3 \mathrm{kWh}_{\mathrm{th}} \mathrm{m}^{-3}$ ) via $168.4 \mathrm{~m}^{3}$ of daily groundwater flow.

\section{Discussion}

\subsection{Climatic Conditions during the Experimental Periods}

The climatic weather conditions at the experimental site represent a classic winter in this region. The inside temperatures of the farrowing barn and piglet-rearing barn (cf. Figure 4) shows a constant and good climate during the test period. The barn inside temperatures correspond to the requirements described in the introduction.

\subsection{Groundwater Heat Pumps}

The degree of utilization of the heat pumps was relatively low because the dimensions of the investigated heat pumps were subsequently doubled for both stables. By doubling the size of the farrowing barn, a power deficit in the heat pump occurred with a nominal power of $40 \mathrm{~kW}$, which could be balanced using hot air blowers. The produced heat output of the heat pump in the piglet-rearing barn was as expected from the sizing of the system. No additional costs will be incurred by the future extension of the same piglet-rearing barn construction after the heat transfer system establishing in the compartments. In this case, the nominal power will be $80 \mathrm{~kW}$. 
As described in the introduction, German authorities must approve the extraction and recirculation of the groundwater when a GWHP is used. On this experimental site, the approval by the German Water Act went without a problem. The groundwater quality fully met the legal requirements. Manganese or iron deposits on the exchanger surfaces were not found by inspecting the barn facilities.

During the experimental period, the extraction well had a daily average groundwater quantity of $99.1 \mathrm{~m}^{3}$ for the heat pump circuit in the farrowing barn and $168.4 \mathrm{~m}^{3} \mathrm{~d}^{-1}$ in the piglet-rearing barns (Section 3.5.; Figure 7). An average of $69.3 \mathrm{~m}^{3} \mathrm{~d}^{-1}$ more groundwater was pumped through the system in the piglet-rearing barn than in the farrowing barn, corresponding to an additional groundwater consumption of $69.9 \%$. It is mentioned by Matthias [17] that the groundwater flow capacity required for the operation of a GWHP is $48 \mathrm{~m}^{3} \mathrm{~d}^{-1}$. The measured values exceeded the specified value in the literature by a factor of 2.1 to 3.5. However, the investigated GWHPs achieved only approximately $50 \%$ of their theoretical capacities. Accordingly, the extracted groundwater requirements should increase at full capacity.

Regarding the required groundwater circuit capacity for the extraction well, it should be noted that this capacity depends on the system performance, the type of application, and the choice of groundwater flow rate. Therefore, fixed guide values cannot be provided at this time.

Cremer [29] estimates the possibility of using heat pumps in livestock buildings because of the relatively low temperature supply (approx. $45^{\circ} \mathrm{C}$ ) when low-temperature warm-water heaters are used efficiently and, thus, economically. The piglet nests in the farrowing barn were operated with a warm-water supply temperature of $45^{\circ} \mathrm{C}$. Only a very small portion of the produced heat $(0.9 \%)$ was required to heat the $50^{\circ} \mathrm{C}$ domestic water. The supply temperature of the heating circuit mentioned by Cremer [29] was exceeded by $5{ }^{\circ} \mathrm{C}$ in the investigated piglet-rearing barn. The observed temperature accounted for $50^{\circ} \mathrm{C}$. Due to the increased supply temperature, negative effects are already expected in the development of the COP for the heat pump system.

\subsection{Comparison with Other Heat Pumps Systems}

The COP values achieved were between 2.5 and 3.4. The price development for primary energy must be considered when comprehensively evaluating this system. By increasing fossil energy prices, the heat pump can be economically operated, even at COP values less than 4.0, compared to conventional fossil heating. However, the value 4.0 fluctuates depending on price of fossil heating energy costs.

To improve the COP of the heat pump, the groundwater flow was increased and the supply temperature in the farrowing barn decreased. Accordingly, the temperature difference between the heat source and heat sink was reduced, thereby improving the COP. This modification was halted after a short time because the desired lying area temperature of approximately $38-40{ }^{\circ} \mathrm{C}$ in the farrowing barn was no longer reached in the farrowing barn due to the lower supply temperature.

The COP serves as the base value for comparing heat pumps (see Section 1). Due to a lack of literature references relating to the use of heat pumps in livestock stables, a direct comparison can only be made to the research of Cremer [29], considering the assessment limits (Figure 3b). Table 1 shows that $\mathrm{COP}_{\mathrm{P}}$ and $\mathrm{COP}_{\mathrm{T}}$ in the present study are largely identical to those of the study of Cremer [29] (investigation of a piglet-rearing barn and farrowing barn with brine heat pump with area collectors). Furthermore, it becomes clear that the $\mathrm{COP}_{Z}$ in both studies are significantly higher than $\mathrm{COP}_{\mathrm{T}}$ and $\mathrm{COP}_{\mathrm{P}}$. This effect is due to the electricity consumption by the GFP (in this study) and the brine pump for the area collectors (at Cremer [29]). Furthermore, the heat transport from the heat pump into the barn itself is decisive for the COP value. Cremer investigated an outdoor climate piglet rearing house (1100 animal places) in which the heat pump was used to heat cubicles with underfloor heating [29]. In the piglet-rearing barn of this study, the heat in the compartments is distributed via four parallel steel tubes as space heating (see Section 2.1). This requires a higher water circulation; the flow temperature is negatively influenced and the temperature difference between sink and source is increased. These 
factors also influence the efficiency of the entire heating system, but to a lesser extent than the feed pump for the groundwater.

The shares of electrical consumers in total electricity consumption in both studies are comparable (Table 1): the highest share is due to the operation of the heat pump itself, followed by the pumping technology for the medium (from the sink to the heat pump). The smallest share of electrical energy is used for the distribution of heat in the stable system.

The evaluation of the COP varies. While Lucia et al. [19] report that the COP of ground-source heat pumps ranges from 3.0 to 3.8, Matthias [17] points out that a COP greater than 4.0 should be targeted for heat pumps in order to ensure economical operation. It should be noted that the $\mathrm{COP}_{\mathrm{T}}$ number is largely dependent on the dimensioning of the overall system (heat pump, circulating or feed pump, circulating pumps for heat transfer into the building, and the technique for heat dissipation) and requires careful dimensioning.

\subsection{Substitution Potential Power of Fossil Energy and a Contribution to $\mathrm{CO}_{2}$ Savings}

A reduction in $\mathrm{CO}_{2}$ emissions is also important for achieving the defined climate protection targets (cf. Section 1). Agricultural livestock farming can contribute to this by using renewable energies. By using heat pumps in this study, 47,160 kWh (piglet-rearing barn) and 36,500 kWh (farrowing barn) of thermal energy could be generated (Section 3.3). If this amount of heat had to be generated with fossil fuels, $4716 \mathrm{~L}$ of fuel oil or $7178 \mathrm{~L}$ of liquid gas would have been required for the piglet house, and $3650 \mathrm{~L}$ of fuel oil or $5556 \mathrm{~L}$ of liquid gas for the farrowing house. Consequently, the use of heat pumps in this experiment avoided 8.5-12.5 tons of $\mathrm{CO}_{2}$ emissions. From an environmental point of view, this is assessed positively.

The avoidance of $\mathrm{CO}_{2}$ emissions by using heat pumps is confirmed by Islam et al. [33]. These authors also report that in their experiment other emissions (ammonia, hydrogen sulfide, sulfur dioxide) besides $\mathrm{CO}_{2}$ were also significantly reduced.

\subsection{Groundwater Heat Pump Compared to Oil or Gas Heating}

It is not easy to make a direct comparison between the groundwater heat pump and an oil or gas heating system, since any comparison is very much dependent on the respective calculation bases and the energy prices, which, as is well known, can fluctuate very strongly. Nevertheless, a rough calculation was made. The following systems were placed side by side: a groundwater heat pump with a $\mathrm{COP}_{\mathrm{T}}$ of 2.7, a groundwater heat pump with a $\mathrm{COP}_{\mathrm{T}}$ of 3.5 , a natural gas heating system, and an oil heating system. The nominal heating capacity of all heating systems is $120 \mathrm{~kW}$ each. The annual heating requirement is estimated at 400,000 $\mathrm{kWh}$. The electric power is always taken into account with a net electricity price of $€ 0.18 \mathrm{kWh}^{-1}$. The acquisition costs for the heat pump are estimated at $€ 44,300$ and for the oil and natural gas heating each at $€ 17,000$. Interest rate $(3.5 \%)$ and depreciation over 10 years (incl. dept service) as well as maintenance cost are considered. The only variable factor in the calculation is the energy prices for oil and natural gas over the last 10 years (annual average values). This result of this calculation is shown graphically in Figure 8. For better understanding, trend lines were inserted. 


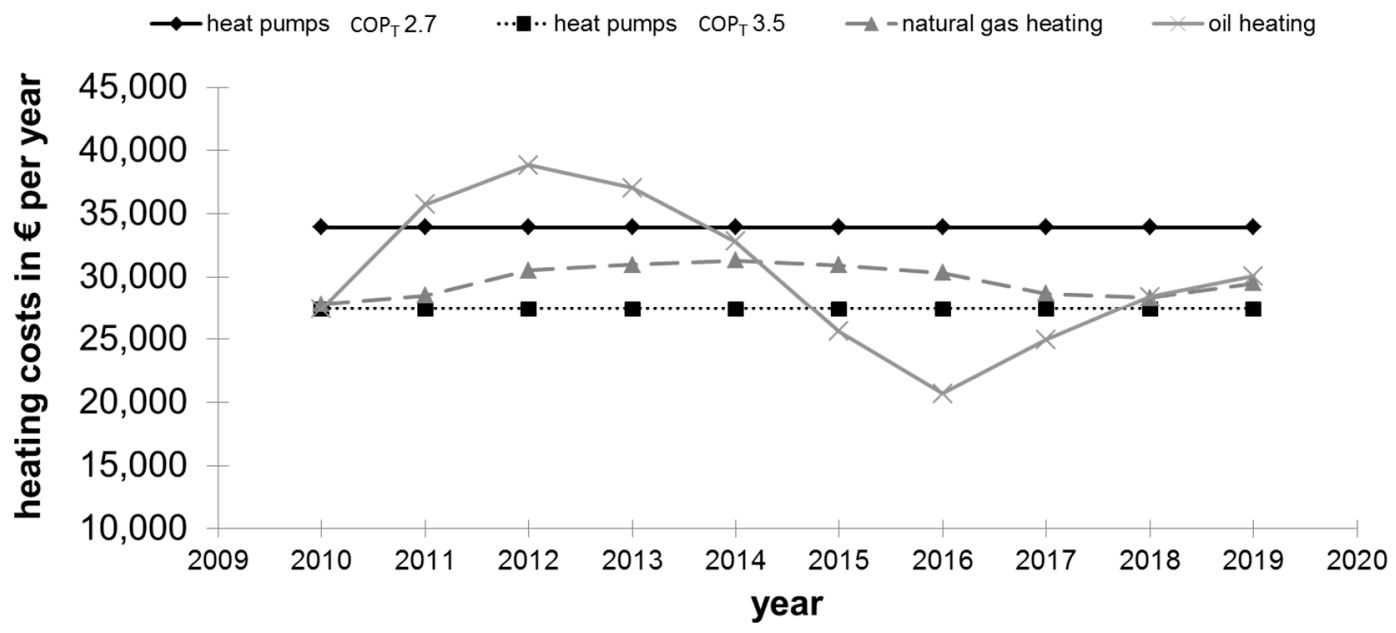

Figure 8. A comparison of the annual heating costs for four different heating systems (a groundwater heat pump with a $\mathrm{COP}_{\mathrm{T}}$ of 2.7 , a groundwater heat pump with a $\mathrm{COP}_{\mathrm{T}}$ of 3.5 , a natural gas heating system and an oil heating system) over the last 10 years. The only variable factor is the energy price (annual average) for oil and natural gas.

The graphs of the heat pumps in Figure 8 run parallel to the abscissa, since the heat pumps are operated independently of oil or natural gas. However, the influence of the COP is very clear. With a COP of 3.5, the performance ratio is significantly better, which is also associated with significantly lower annual costs. There is a clear link between the annual costs of natural gas and oil heating and energy prices, although the oil price usually fluctuates more strongly than the natural gas price. In the years 2011 to 2013, heat pump operation is even more economical than oil heating, even with a poor COP of 2.7, so the farm owner's decision to use heat pump technology in 2009 is understandable in view of rising energy prices (at that time). In the following years, on the other hand, operation with an oil heating system would have been cheaper than with a heat pump, because the oil price has fallen relatively sharply again.

The operation of a natural gas heating system is a sensible alternative if a sufficiently high COP number for heat pump operation cannot be guaranteed. However, it must be considered that natural gas is not available in all areas.

If the price of electricity continues to rise and natural gas and oil prices should stagnate, a heat pump is not recommended under current conditions.

\section{Conclusions}

The present study of two heat pump systems contributes to the practical analysis of the performance of regenerative heating technologies. Heat pumps can be characterized realistically in terms of the relationship between electricity consumption and both energy production and energy efficiency. The economic and ecological operation of a groundwater heat pump depends on achieving a high coefficient of performance. For this purpose, the lowest possible flow temperatures of the compartment heating circuit should be selected, as this is the only way to ensure a small temperature difference between the heat source (ground water) and the heat sink (heating circuit flow) at a relatively constant ground water temperature. For this reason, the installation of a groundwater heat pump, it is essential to adjust the heating regime in the barn compartments to low heating circuit flow temperatures.

The following aspects should be considered when installing a GWHP in a farrowing barn or a piglet rearing barn:

- The warm-water piglet heater is preferable to the space heating variants due to the lower flow temperature. 
- Hot water pipes of the heating circuit should be thermally insulated. As a result, the transport heat losses remain low and the flow temperatures can be selected lower, correspondingly.

- In addition, the warm-water piglet heater should be routed in a parallel proceeding to ensure a homogeneous heat distribution in the common area of the animals.

- The radiating surface of the heating elements in the animal house must be sufficiently large.

- The lying area should be provided with a heat protection cover. As a result, the animals can be provided with an optimal microclimate even at low heating circuit flow temperatures.

The above-mentioned installation recommendations represent an opportunity to minimize flow temperature. This describes the most important and influenceable regulating variable for an economic and ecological operation of a GWHP.

In addition, the following points can be noted:

- The permanently constant ground water temperature has a positive effect on the performance of a heat pump.

- However, pumping groundwater requires a considerable amount of electrical power by the groundwater feeding pump.

- The heat pump was oversized for the stable complex under investigation. (Background: the barn should be doubled at a later date. However, the heat pumps were dimensioned directly for the entire building.)

- The application of the three different assessment limits could help to identify factors influencing the coefficient of performance.

- The high supply temperature of $50{ }^{\circ} \mathrm{C}$ in the piglet rearing barn has a negative effect on the COP. It is recommended that the radiating area in the house is increased (up to now only steel tubes have been installed here), so that the required heat output in the house can still be ensured at low supply temperature.

- The data collected refer to the winter.

- Against the background of the sharp drop in feed-in tariffs for electricity from photovoltaic systems in Germany, it should be examined whether it makes sense to install a photovoltaic system on the roof surfaces to generate electricity. On the one hand, the use of self-generated electricity could lead to becoming somewhat more independent of the energy market. On the other hand, the operation of the heat pump could become more economical if the kilowatt hour of electrical power generated on the own farm is cheaper than the kilowatt hour purchased from the network provider.

It would be desirable if such a heat pump system were examined over a whole year in order to obtain a holistic picture of the groundwater heat pump and its performance over all seasons. It would also be interesting to check whether a combination of heat pumps with other house systems makes sense. In this connection, a modular housing system with geothermal heat exchanger, for example, could be combined with a brine heat pump. The brine circuit of the heat pump could be integrated into the central exhaust air collecting duct of the modular house. The exhaust air could thus be extracted at a high temperature. This installation would have the advantage of a lower temperature difference between the heat source (warm exhaust air) and heat sink (heating circuit), which should result in a higher COP. However, a more secure and continuous outflow in the exhaust air-collecting duct of the condensate should be ensured to prevent building damage. However, other solutions are also conceivable. A very important future research question in times of global warming is to what extent heat pump systems can be used not only for heating in winter but also for cooling in summer (cf. $[32,34,35]$ ) and which modifications are associated with this.

Author Contributions: Conceptualization, H.L., P.R., M.S.K. and W.B.; Methodology, H.L., P.R. and W.B.; Software, H.L. and P.R.; Validation, H.L., P.R. and M.S.K.; Formal Analysis, H.L. and P.R.; Investigation, H.L. and P.R.; Resources, W.B.; Data Curation, H.L., P.R. and M.S.K.; Writing—Original Draft Preparation, H.L. and M.S.K.; 
Writing-Review and Editing, H.L., M.S.K., E.M. and W.B.; Visualization, H.L. and P.R.; Supervision, M.S.K. and W.B.; Project Administration, W.B.; Funding Acquisition, P.R. and W.B. All authors have read and agreed to the published version of the manuscript.

Funding: This research was founded by the Lehr- und Forschungsschwerpunkt "Umweltverträgliche und Standortgerechte Landwirtschaft" (USL).

Acknowledgments: The authors thank the farm owner for the permission to carry out the experiments on his farm. They would also like to thank Gerd-Christian Maack (Institute of Agricultural Engineering, University of Bonn) for his assistance and discussion of the results and for preparing Figure 8, and Hauke F. Deeken (Institute of Agricultural Engineering, University of Bonn) for preparing Figure 2a.

Conflicts of Interest: The authors declare no conflict of interest.

\section{Abbreviations and Indices}

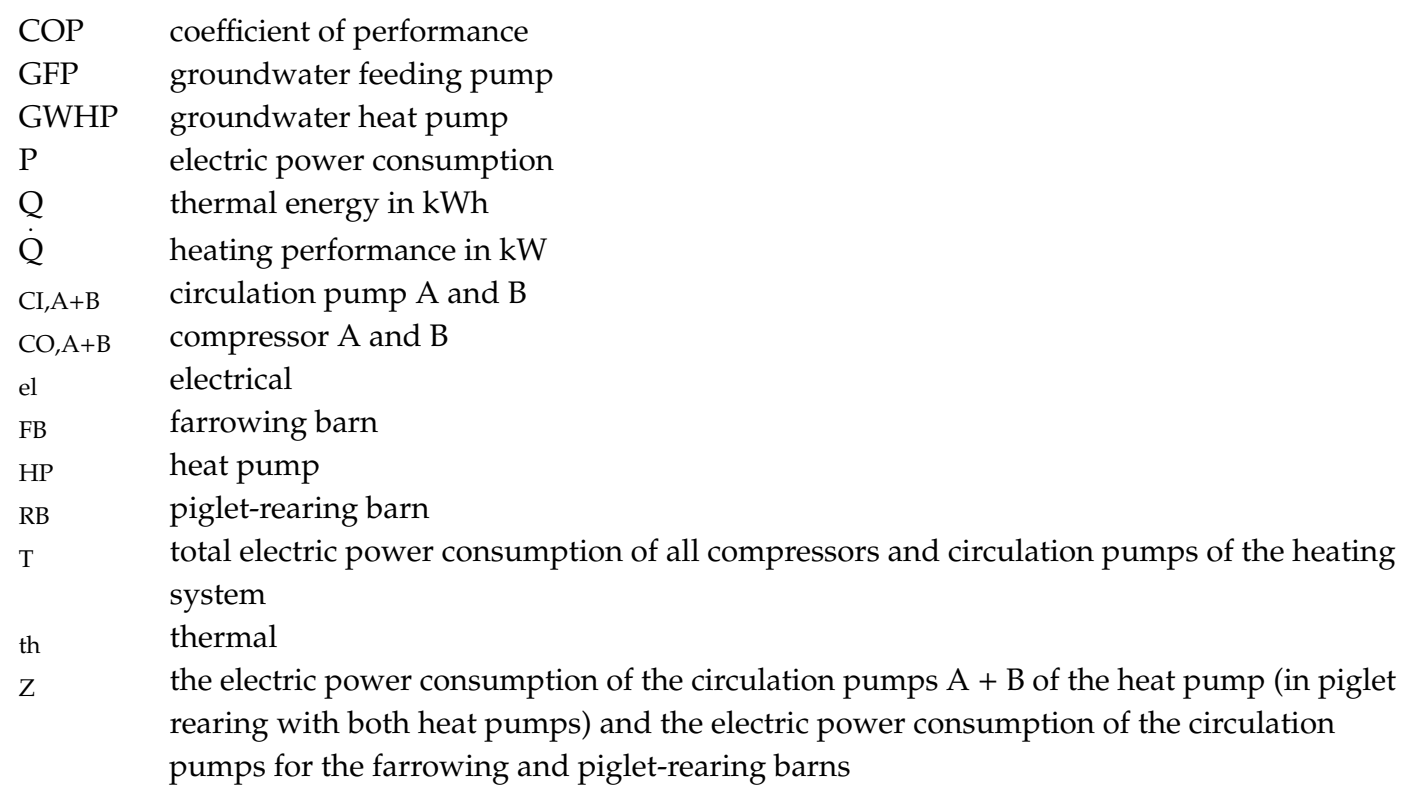

\section{References}

1. German Environment Agency. Climate Footprint 2018: 4.5 Percent Decrease in Greenhouse Gas Emissions. German Environment Agency Produces Initial Detailed Estimate. 2019. Available online: https://www. umweltbundesamt.de/en/press/pressinformation/climate-footprint-2018-45-percent-decrease-in (accessed on 15 January 2020).

2. Corré, W.; Schröder, J.; Verhagen, J. Energy use in conventional and organic farming systems. In Proceedings of the Open Meeting of the International Fertiliser Society, London, UK, 3 April 2003; London International Fertiliser Society: York, UK, 2003. ISBN 0-85310-147-7. ISSN 1466-1314.

3. Krommweh, M.S.; Rösmann, P.; Büscher, W. Investigation of heating and cooling potential of a modular housing system for fattening pigs with integrated geothermal heat exchanger. Biosyst. Eng. 2014, 121, 118-129. [CrossRef]

4. Büscher, W. Energiebedarf und Leistungsbereitstellung in der Schweinehaltung. In Baubriefe Landwirtschaft e. V. 47; Landwirtschaftsverlag GmbH: Münster-Hiltrup, Germany, 2009; pp. 10-15.

5. Heinritzi, K.; Gindele, H.R.; Reiner, G.; Schnurrbusch, U. Allgemeiner Untersuchungsgang. In Schweinekrankheiten, UTB 8325; Verlag Eugen Ulmer KG: Stuttgart, Germany, 2006; pp. 18-22.

6. European Commission. Best Available Techniques (BAT) Reference Document for the Intensive Rearing of Poultry or Pigs, Industrial Emissions Directive 2010/75/EU Integrated Pollution Prevention and Control; EU 28674 EN; Publication Office of the European Union: Luxemburg, 2017. [CrossRef]

7. Meyer, E.; Vogel, M.; Wähner, M. Investigations on acceptance and size of piglet nests. Landtechnik 2012, 67, 362-365. 
8. DIN 18910:2017-08. Thermal Insulation for Closed Livestock Buildings-Thermal Insulation and Ventilation-Principles for Planning and Design for Closed Ventilated Livestock Buildings; DIN Deutsches Institut für Normung e. V., Ed.; Beuth Verlag GmbH: Berlin, Germany, 2017.

9. Büscher, W.; Cremer, P.; Feller, B.; Fritzsche, S. Lüftung und Wärmedämmung geschlossener Ställe—Bemessung nach DIN 18910:2017-08; Sonderveröffentlichung, Ed.; Kuratorium für Technik und Bauwesen in der Landwirtschaft e. V. (KTBL): Darmstadt, Germany, 2018; ISBN 978-3-945088-61-6.

10. Lindley, J.A.; Whitaker, J.H. Agricultural Buildings and Structures; ASAE (The Society for Engineering in Agricultural, Food, and Biological Systems): St. Joseph, MI, USA, 1996; pp. 249-270, 347-356. ISBN 978-0-929355-73-3.

11. Spengler, R.W.; Stombaugh, D.P. Optimization of earth-tube heat exchangers for winter ventilation of swine housing. Trans. ASAE 1983, 26, 1186-1193. [CrossRef]

12. Van Caenegem, L. Energieeffizienz in Abferkelställen Durch Erdwärmenutzung, Energieeffiziente Landwirtschaft; KTBL-Schrift 463; Kuratorium für Technik und Bauwesen in der Landwirtschaft e. V. (KTBL): Darmstadt, Germany, 2008; pp. 162-172. ISBN 978-3-939371-59-5.

13. Rösmann, P.; Büscher, W. Rating of an air-to-air heat exchanger in practice. Landtechnik 2010, 65, 418-420. [CrossRef]

14. Allen, W.H.; Payne, F.A. Designing animal ventilation schedules with counterflow heat exchangers. Trans. ASAE 1987, 30, 782-788. [CrossRef]

15. VDI 3803-5. VDI-Richtlinie 3803-5: Air-Conditioning, System Requirements. Part 5: Heat Recovery Systems; Verein Deutscher Ingenieure e. V. (VDI), Ed.; Beuth Verlag GmbH: Berlin, Germany, 2013.

16. Recknagel, H.; Sprenger, E.; Albers, K.J. Taschenbuch für Heizung und Klimatechnik, Band 1; Deutscher Industrieverlag GmbH (DIV): München, Germany, 2015; p. 1035. ISBN 978-38356-7136-2.

17. Matthias, J. Wärmepumpen zur Stallbeheizung. In Baubriefe Landwirtschaft e. V. 47; Landwirtschaftsverlag GmbH: Münster-Hiltrup, Germany, 2009; pp. 70-72. ISBN 978-3-7843-3410-3.

18. Baumann, M.; Laue, H.-J.; Müller, P. Wärmepumpen-Heizen mit Umweltenergie, 4. Erweiterte und Vollständig Überarbeitete Auflage, BINE Informationsdienst; Verlag Solarpraxis AG: Berlin, Germany, 2007; ISBN 978-3-934595-60-6.

19. Lucia, U.; Simonetti, M.; Chiesa, G.; Grisolia, G. Ground-source pump system for heating and cooling: Review and thermodynamic approach. Renew. Sustain. Energy Rev. 2017, 70, 867-874. [CrossRef]

20. VDI 4645:2018-03. VDI-Guideline 4645: Heating Plants with Heat Pumps In Single-Family and Multi-Family Houses, Planning, Construction, Operation; Verein Deutscher Ingenieure e. V. (VDI), Ed.; Beuth Verlag GmbH: Berlin, Germany, 2018.

21. Omer, A.M. Ground-source heat pumps systems and applications. Renew. Sustain. Energy Rev. 2008, 12, 344-371. [CrossRef]

22. Ahmadi, M.H.; Ahmadi, M.A.; Sadaghiani, M.S.; Ghazvini, M.; Shahriar, S.; Nazari, M.A. Ground source heat pump carbon emissions and ground-source heat pump systems for heating and cooling of buildings: A review. Environ. Progress Sustain. Energy 2017, 37, 1241-1265. [CrossRef]

23. Tissen, C.; Menberg, K.; Bayer, P.; Blum, P. Meeting the demand: Geothermal heat supply rates for an urban quarter in Germany. Geother. Energy 2019, 7, 9. [CrossRef]

24. Zurmühlen, S.; Wolisz, H.; Angenendt, G.; Magnor, D.; Streblow, R.; Müller, D.; Sauer, D.U. Potential and Optimal Sizing of Combined Heat and Electrical Storage in Private Households. Energy Procedia 2016, 99, 174-181. [CrossRef]

25. Meng, B.; Vienken, T.; Kolditz, O.; Shao, H. Modeling the groundwater temperature response to extensive operation of ground source heat pump systems: A case study in Germany. Energy Procedia 2018, 152, 971-977. [CrossRef]

26. Ziegler, T.; Teodorov, T.; Mellmann, J. Fixed bed drying of medicinal plants using dehumidification of air. Landtechnik 2011, 66, 167-169. [CrossRef]

27. Benli, H.; Durmus, A. Evaluation of ground-source heat pump combined latent heat storage system performance in greenhouse heating. Energy Build. 2009, 41, 220-228. [CrossRef]

28. Tong, Y.; Kozai, T.; Nishioka, N.; Ohyama, K. Greenhouse heating using heat pumps with a high coefficient of performance (COP). Biosyst. Eng. 2010, 106, 405-411. [CrossRef]

29. Cremer, P. Wärmepumpeneinsatz in Landwirtschaftlichen Betrieben-Hinweise und Beispiele; Förderkreis Stallklima: Dummerstorf, Germany, 2011. 
30. Lücke, W.; Hörsten, D. Utilising Heat in Roofs for Energy Generation in Agricultural Buildings. Landtechnik 2006, 61, 208-209. [CrossRef]

31. Riva, G.; Pedretti, E.F.; Fabbri, C. Utilization of a Heat Pump in Pig Breeding for Energy Saving and Climate and Ammonia Control. J. Eng. Res. 2000, 77, 449-455. [CrossRef]

32. Manolakos, D.; Panagakis, P.; Bartzanas, T.; Bouzianas, K. Use of heat pumps in HVAC systems for precise environment control in broiler houses: System's modeling and calculation of the basic design. Comput. Electron. Agric. 2019, 163, 104876. [CrossRef]

33. Islam, M.M.; Mun, H.-S.; Rubayet Bostami, A.B.M.; Ahmed, S.T.; Park, K.-J.; Yang, C.-J. Evaluation of a ground source geothermal heat pump to save energy and reduce $\mathrm{CO}_{2}$ and noxious gas emissions in a pig house. Energy Build. 2016, 111, 446-454. [CrossRef]

34. Alberti, L.; Antelmi, M.; Angelotti, A.; Formentin, G. Geothermal heat pumps for sustainable farm climatization and field irrigation. Agric. Water Manag. 2018, 195, 187-200. [CrossRef]

35. Wang, M.Z.; Wu, Z.H.; Chen, Z.H.; Tian, J.H.; Liu, J.J. Economic Performance Study on the Application of Ground Source Pump System in Swine Farms in Beijing China. AASRI Procedia 2012, 2, 8-13. [CrossRef]

36. Rösmann, P. Einsatz von Regenerativen Energiequellen zum Heizen und Kühlen von Zwangsbelüfteten Tierställen. Ph.D. Thesis, Rheinische Friedrich-Wilhelms-Universität Bonn, Bonn, Germany, 2012.

37. Costantino, A.; Fabrizio, E.; Ghiggini, A.; Bariani, M. Climate control in broiler houses: A thermal model for the calculation of the energy use and indoor environmental conditions. Energy Build. 2018, 169, 110-126. [CrossRef]

(C) 2020 by the authors. Licensee MDPI, Basel, Switzerland. This article is an open access article distributed under the terms and conditions of the Creative Commons Attribution (CC BY) license (http://creativecommons.org/licenses/by/4.0/). 